\title{
Die wirtschaftliche Erwachen Asiens
}

Le réveil économique de l'Asie

Jean-Luc Maurer

\section{OpenEdition}

Journals

Édition électronique

URL : http://journals.openedition.org/sjep/1111

DOI : 10.4000/sjep. 1111

ISSN : 1663-9677

Éditeur

Institut de hautes études internationales et du développement

Édition imprimée

Date de publication : 1 décembre 1989

Pagination : 127-136

ISSN : 1660-5926

Référence électronique

Jean-Luc Maurer, « Die wirtschaftliche Erwachen Asiens », Schweizerisches Jahrbuch für

Entwicklungspolitik [En ligne], 8| 1989, mis en ligne le 13 mars 2013, consulté le 08 septembre 2020

URL : http://journals.openedition.org/sjep/1111 ; DOI : https://doi.org/10.4000/sjep.1111

Ce document a été généré automatiquement le 8 septembre 2020

(c) The Graduate Institute 


\section{Die wirtschaftliche Erwachen Asiens}

Le réveil économique de l'Asie

Jean-Luc Maurer

NOTE DE L'ÉDITEUR

auf Französisch in Annuaire suisse de politique de développement: „Le réveil économique de l'Asie", http://aspd.revues.org/1282.

\section{AUTEUR}

JEAN-LUC MAURER

Chargé de cours, IUED, Genève 